\title{
Recent advances in mechanisms of food allergy and
}

\section{anaphylaxis [version 1; peer review: 2 approved]}

\author{
Sunil Tomar, Simon P Hogan
}

1. Mary H. Weiser Food Allergy Center, Department of Pathology, University of Michigan 4051-BSRB, 109 Zina Pitcher Place, Ann Arbor, MI, 48109-2200, USA

V1 First published: 31 Jul 2020, 9(Faculty Rev):863

https://doi.org/10.12688/f1000research.25638.1

Latest published: 31 Jul 2020, 9(Faculty Rev):863

https://doi.org/10.12688/f1000research.25638.1

\section{Open Peer Review \\ Approval Status \\ 1 \\ 2 \\ version 1 \\ 31 Jul 2020 \\ Faculty Reviews are review articles written by the prestigious Members of Faculty Opinions. The articles are commissioned and peer reviewed before publication to ensure that the final, published version is comprehensive and accessible. The reviewers who approved the final version are listed with their names and affiliations.}

1. Hans Oettgen, Boston Children's Hospital, Boston, USA

2. Michael D Kulis, University of North Carolina at Chapel Hill, Chapel Hill, USA

Any comments on the article can be found at the end of the article. 
Corresponding author: Simon P Hogan (sihogan@med.umich.edu)

Author roles: Tomar S: Conceptualization, Writing - Original Draft Preparation, Writing - Review \& Editing; Hogan SP:

Conceptualization, Project Administration, Supervision, Writing - Original Draft Preparation, Writing - Review \& Editing

Competing interests: S. P. H is the co-inventor on patent PCT/US2018/018618 Inhibition of Unfolded Protein response for Suppressing or preventing allergic reaction to food. S. T declares no competing interests.

Grant information: This work was supported by National Institutes of Health (NIH) DK073553, AI112626, AI138177, AI140133,

Department of Defense (DoD) W81XWH-15-1-051730 (S. P. H.) and Food Allergy Research \& Education, M-FARA and Mary H. Weiser Food Allergy Center (S. P. H).

The funders had no role in study design, data collection and analysis, decision to publish, or preparation of the manuscript.

Copyright: @ 2020 Tomar S and Hogan SP. This is an open access article distributed under the terms of the Creative Commons Attribution License, which permits unrestricted use, distribution, and reproduction in any medium, provided the original work is properly cited.

How to cite this article: Tomar S and Hogan SP. Recent advances in mechanisms of food allergy and anaphylaxis [version 1; peer review: 2 approved] F1000Research 2020, 9(Faculty Rev):863 https://doi.org/10.12688/f1000research.25638.1

First published: 31 Jul 2020, 9(Faculty Rev):863 https://doi.org/10.12688/f1000research.25638.1 


\section{Anaphylaxis}

Anaphylaxis is a serious and life-threatening generalized or systemic allergic or hypersensitivity reaction which is rapid in onset (minutes to a few hours) $)^{1,2}$. Anaphylaxis diagnosis is based upon the involvement of at least two organs system including skin/cutaneous, gastrointestinal (GI), respiratory, cardiovascular, and neurologic systems ${ }^{2-5}$. While foods remain the most common cause of anaphylaxis, other causative agents include medicines and insect stings ${ }^{2}$.

Recently, the European Academy of Allergy and Clinical Immunology (EAACI) and the American Academy of Allergy, Asthma, and Immunology (AAAAI) published a consensus document to propose a new approach to personalized treatment for patients of food allergy, drug allergy, and anaphylaxis ${ }^{2,6}$. The personalized medicine approach, termed precision medicine, would be guided by underlying cellular or molecular mechanisms, termed endotypes, and associated diagnostic biomarkers rather than the clinical presentation of clinical symptoms of anaphylaxis, termed phenotype ${ }^{2,6}$. It is anticipated that better clinical outcomes would be achievable if treatments were tailored according to the specific cellular/molecular characteristics (endotype) rather than clinical characteristics of a patient (phenotype) ${ }^{6}$. Two recent reviews have described the phenotypes, endotypes, and biomarkers to aid the diagnosis of anaphylaxis in great detail ${ }^{2,6}$. Proposed anaphylaxis endotypes include immunoglobulin ( $\mathrm{Ig}$ ) E-mediated and non-IgE-mediated type I reactions, cytokine release reactions, mixed reactions, and complement or bradykinin-mediated direct activation of mast cells (MCs) and basophils ${ }^{2,6,7}$. The development of precision medicine for anaphylaxis is going to be reliant on future research in the underlying cellular and molecular processes that drive food sensitization and anaphylactic reactions and the identification of specific biomarkers to predict anaphylaxis endotypes, severity of reaction, and clinical outcome with treatments ${ }^{6}$. Herein, we will describe recent advancements in our understanding of the underlying immunological processes that regulate oral tolerance versus food sensitization, mechanisms of dietary antigen sampling, severity of anaphylactic reactions, and oral immunotherapy outcomes.

\section{Oral tolerance versus sensitization}

To prevent the development of systemic immune responsiveness to innocuous dietary protein antigens, the immune system has developed mechanisms of local and systemic immune unresponsiveness termed "oral tolerance" ${ }^{8-10}$. Luminal soluble dietary protein antigens are acquired by small intestine (SI) lamina propria (LP) $\mathrm{CX}_{3} \mathrm{CR}^{+}$macrophages and $\mathrm{CD}^{+} 03^{+}$ migratory dendritic cells (DCs) that migrate via the afferent lymphatic vessels to selective duodenal gut-draining lymph nodes, where they present dietary antigens via cognate interaction to naive $\mathrm{CD}^{+} \mathrm{T}$ cells ${ }^{11-13}$. $\mathrm{CD} 103^{+} \mathrm{DC}$-derived retinoic acid (RA), indoleamine 2,3-dioxygenase (IDO), and transforming growth factor (TGF)- $\beta$ promote de novo Foxp3 expression and generation of peripheral regulatory $\mathrm{T}$ cells (Tregs) and expression of gut-specific homing receptors including CCR9 and $\alpha 4 \beta 7$-integrin ${ }^{12-15}$. The newly derived CD4 ${ }^{+}$Treg cells traffic back to the SI LP, where they undergo proliferation and maintain a tolerant homeostatic environment through secretion of the cytokines TGF- $\beta$ and interleukin (IL)-10 ${ }^{16}$. Tregs, specifically peripheral Tregs, and not thymus-derived Tregs, are critical for establishing oral tolerance ${ }^{16-19}$. Increased frequencies of Tregs are associated with outgrowing early on cow's milk allergy, while lower Treg frequencies have been noted in atopic young children with food allergy ${ }^{20,21}$. The Foxp $3^{+}$ $\mathrm{CD}^{+}{ }^{+}$Treg cells are maintained and supported by additional regulatory cells positioned within the SI mucosa, including $\mathrm{MHCII}^{+} \mathrm{CX}_{3} \mathrm{CR} 1^{\mathrm{Hi}}$ IL-10-producing macrophages, gut-resident type 3 innate lymphoid cells (ILC3s), and regulatory B cells $(\text { Bregs })^{16}$. Microbial-sensing intestinal macrophages secrete IL-1 $\beta$ to stimulate ILC3-derived GM-CSF, which supports DC secretions of RA and IL-10 $0^{22}$. Furthermore, gut-resident ILC3s through IL-22 secretion promote enhanced barrier function and reduce permeability to dietary antigens ${ }^{23}$. Bregs contribute to tolerance through the production of IL-10, TGF- $\beta$, and IL-35 ${ }^{24}$. Extrathymically derived peripheral RA receptor (RAR)-related orphan receptor gamma $t(\mathrm{ROR} \gamma \mathrm{t})^{+}$Tregs support a protective mucosal $\mathrm{T}$ regulatory response and enhancement of intestinal epithelial barrier integrity ${ }^{25-28}$. Furthermore, this tolerogenic state is reinforced by protective commensal microbes and their metabolites such as short-chain fatty acids (SCFAs) (e.g. acetate, propionate, and butyrate) that bind to G-proteincoupled receptors (GPR43 [free fatty acid receptor (FFAR)-2], GPR41 [FFAR3], and GPR109A) ${ }^{29}$.

In disease states such as food allergy, these tolerogenic mechanisms are thought to be dysregulated, triggering the development of a food-specific "sensitizing" IgE response that can predispose to food allergy and anaphylaxis upon subsequent food exposures. In these individuals, food allergen exposure leads to the production of the pro-type- 2 epithelial-derived cytokines IL-25, IL-33, and thymic stromal lymphopoietin $(\mathrm{TSLP})^{30}$. The array of stimuli that can elicit an initial prototypic type- 2 cytokine response is not yet fully elucidated. Experimental evidence suggests that dietary saturated fats such as medium-chain triglycerides (MCTs) are sufficient to promote SI epithelial-derived IL-25, IL-33, and TSLP production, driving a CD4 ${ }^{+} \mathrm{T}$ helper type 2 (Th2) response and food sensitization $^{31}$. MCTs are thought to induce an endoplasmic reticulum stress and unfolded protein response within the GI epithelia, leading to induction of IL-25, IL-33, and TSLP $^{32,33}$. The pro-type-2 cytokines are thought to act on $\mathrm{CD}_{103}{ }^{+} \mathrm{DC}$ cells to promote OX40L expression, which drives the IL-4-dependent CD4 ${ }^{+}$Th2 cells and $\mathrm{CD} 4^{+} \mathrm{Th} 9$ cells $^{34-36}$, and stimulate ILC2-derived cytokines (IL-5 and IL-13), which supports the expansion of basophils and MCs and suppresses Treg function ${ }^{37}$. Induction of the $\mathrm{CD}^{+} \mathrm{IL}^{+} 4^{+} \mathrm{Th} 2$ response leads to class switching of $\mathrm{B}$ cells and production of allergen-specific IgE. Bone marrow and lymph node germinal centers are thought to be the dominant sites of induction of $\operatorname{IgE}^{+}$plasma cells, with the bone marrow providing the major long-term source of $\mathrm{IgE}^{+}$plasma cells in both mice and humans ${ }^{38,39}$. However, a recent study revealed that a number of gastrointestinal compartments including the stomach and duodenum are enriched for food allergen-specific $\operatorname{IgE}^{+}$plasma cells in allergic patients ${ }^{40}$. Furthermore, the investigators observed clonally related 
$\mathrm{IgE}^{+}$and non-IgE-expressing cells in these GI tissues, suggesting isotype switching and induction of $\mathrm{IgE}^{+}$plasma cells in the GI compartment. CD4 $4^{+} \mathrm{IL}-4^{+}$Th2 response has also been shown to promote the development of IL-9-producing mucosal MCs (MMC9s) and mature $\mathrm{MCs}^{41}$. MMC9 cells are hypo-granular immature MC-like cells that perpetuate $\mathrm{MC}$ progenitor (MCp) maturation to mature MCs in SI via an IL-9/IL9R $\alpha$ pathway $^{41-43}$. Post-sensitization, upon subsequent food allergen exposure, dietary antigens cross-link the IgE bound to FceRI on MCs and basophils, leading to the release of mediators, including histamine, platelet-activating factor, serotonin, proteases (tryptase and chymase), and lipid-derived mediators (prostaglandins [PGD2] and leukotrienes [LTC4, LTD4, and LTE4]), which promote the clinical manifestations associated with food-triggered anaphylaxis ${ }^{44,45}$.

\section{Role of microbiota in regulating sensitization versus tolerance}

Recently, a number of studies have established a strong association between changes in microbial populations within the gut microbiota and allergic/tolerogenic states and identify a role for the microbiota in barrier function and permissiveness to the development of $\mathrm{CD}^{+}{ }^{+} \mathrm{Th} 2$ cells and food sensitization ${ }^{46-50}$. Clinical studies have identified that microbial enrichment for Firmicutes, including Clostridium species in children, is associated with outgrowing cow's milk allergy, while decreased Clostridiales and increased Bacteroidales and lower gut overall microbial diversity have been associated with nut and pollen allergy in adults ${ }^{51,52}$. Increased Enterobacteriaceae to Bacteroidaceae ratio and decreased Ruminococcaceae abundance together with low microbial diversity were associated with decreased food sensitization in infants ${ }^{53}$. Consistent with the concept that microbial communities can regulate food sensitization, transfer of microbiota from sensitized mice with increased susceptibility to food allergy (IL-4R $\alpha$ gain-of-function mutation Il4Ra ${ }^{\mathrm{Y} 709 \mathrm{~F}}$ ) confers food allergic susceptibility when transferred into WT mice ${ }^{47}$. Similarly, colonization of mice with intestinal microbiota from cow's milk-allergic infants, but not healthy infants, transferred food allergic susceptibility ${ }^{54}$. Conversely, the presence of the Clostridia species Anaerostipes caccae has been shown to confer protection to mice from food sensitization and anaphylaxis ${ }^{23,54}$. While the molecular basis of microbiotamediated tolerance and sensitization is not fully understood, Clostridia species are thought to promote oral tolerance mechanisms via increased IgA production, expansion of Foxp $3^{+}$ Tregs, $\mathrm{ROR} \mathrm{t}^{+}$ILC3-mediated reinforcement of epithelial barrier through production of IL-22, and increased expression of antimicrobial peptides such as REG3 $\beta$ by intestinal epithelia cells $^{23,55-58}$. Clostridial families including Lachnospiraceae and Ruminococcaceae produce SCFAs, including acetate, propionate, and butyrate, which can mediate tolerogenic/ homeostatic effects through different mechanisms ${ }^{14,55,56}$. SCFAs can bind GPR43 and GPR109A to activate the inflammasome, increasing IL-18 production, which in turn promotes barrier function ${ }^{59,60}$. Butyrate promotes the expansion of colonic Foxp $^{+}$Treg cells by supporting peripheral Treg generation through inhibition of histone deacetylase activity at the Foxp3 promoter $^{61,62}$. Propionate signaling through GPR43 also promotes intestinal Treg expansion ${ }^{63}$. The loss of microbial populations and regulatory metabolites is thought to diminish the tolerogenic immune environment, leading to impaired barrier function and increased systemic food allergens and sensitization ${ }^{50}$.

Several questions remain unanswered regarding the role of microbial communities in mediating tolerance/food sensitization. How do microbial populations that predominantly reside in the large intestine influence food allergic sensitization/tolerance mechanisms which are thought to occur primarily in the SI? Is the development and sustainment of microbiota-driven tolerance dependent on individual species or larger microbial communities? Given the dynamic and complex nature of cross talk among host, microbiota, and environmental cues, longterm longitudinal studies are likely required to obtain better insight into the role of the microbiota in tolerance/allergenic sensitization.

\section{Food antigen sampling}

The anatomical sites of dietary protein antigen uptake and mechanisms that underlie the development of the tolerogenic response and establishment of oral tolerance are not fully illuminated $^{8,9}$. Given the obvious link between orally consumed dietary antigens and induction of food allergy, there has been significant focus on how dietary antigen exposure of the GI tract promotes a tolerogenic or sensitization immune response ${ }^{64,65}$. However, the demonstration of a positive correlation between environmental non-oral peanut protein exposure levels and development of peanut allergy suggests non-oral environmental exposure as a potential route of sensitization ${ }^{66}$. The observed natural history of the "allergic march", whereby individuals presenting with atopic dermatitis (AD) in infancy or early childhood proceed to develop concomitant sensitization to food and aeroallergens in later childhood and adult life, has led to the evolving concept of contribution from the skin as a route of food sensitization ${ }^{67-71}$. An archetypal example is AD, a common inflammatory skin disease in childhood affecting nearly $20-30 \%$ of the population and is associated with skin barrier disruption linked with mutations in human skin barrier genes filaggrin $(F L G)$, serine peptidase inhibitor Kazal type 5 (SPINK5), corneodesmosin $(C D S N)$, and mattrin $(T M E M 79)^{72-74}$. Early onset of $\mathrm{AD}$ is associated with increased risk of allergic sensitization to food allergens by 2 years of age $\mathrm{a}^{75,76}$, and $\mathrm{AD}$-associated risk mutations are risk factors for allergy development including peanut allergy ${ }^{77,78}$. Indeed, IgE-mediated food allergy is observed in up to $35 \%$ of children affected with $\mathrm{AD}^{79}$. Importantly, neonatal skin barrier dysfunction in individuals without $\mathrm{AD}$ also predicts food allergy at 2 years of age $^{75}$. Consistent with this concept, genetic $\left(\right.$ Flgft Tmem79 $\left.{ }^{m a}\right)$, pharmacological, or mechanical disruption of the skin barrier and allergen exposure in mice is associated with food sensitization and food allergy $\mathrm{y}^{80,81}$.

An elegant study by Levya-Castillo et al. recently identified a link between mechanical skin injury and intestinal $\mathrm{MC}$ expansion and induction of food-induced anaphylaxis in mice. The authors showed that skin injury triggered systemic production of keratinocyte-derived IL-33, driving intestinal 
tuft-cell-derived IL-25 production and ILC2 expansion ${ }^{81}$. ILC2s, through their capacity to produce IL-4, drove the expansion of SI MCs, potentiating the effector phase response ${ }^{81}$. Consistent with the concept of disruption to the cutaneous layer and expansion of intestinal MC populations, the authors demonstrated that duodenal MCs were expanded in $\mathrm{AD}$ patients ${ }^{81}$. Collectively, these studies identify a direct mechanism whereby epicutaneous allergen exposure and skin injury can alter the GI environment (increase intestinal MC frequency) and food allergic outcome. Consistent with this, corroborative studies in animal model systems have revealed that food exposure via the skin can promote $\mathrm{CD}^{+} \mathrm{Th} 2$ responses and food allergic reactions ${ }^{81-84}$.

Experimental analyses also suggest that inhalation of food allergens can promote food sensitization and reactions ${ }^{85,86}$. Dolence et al. demonstrated that inhalation of peanut flour allergen in mice leads to the development of food-specific IgE levels and predisposed to food-induced anaphylaxis. Interestingly, draining lymph node-resident $\mathrm{T}$ follicular helper (Tfh) cells that produced type-2 cytokines (IL-4 and IL-21) were shown to be the primary drivers of food-specific $\operatorname{IgE}$ and food-induced anaphylaxis ${ }^{86}$. Interestingly, a recent study revealed that indoor dust may act as an adjuvant and play a role in the exacerbation of inhaled food allergen sensitization. Inhaled indoor dust was shown to stimulate airway epithelial innate cytokine production and maturation, and lung type- 1 cDCs and co-exposure of indoor dust and food allergens such as peanut led to the development of peanut-specific Th2 cell differentiation and the accumulation of Tfh cell peanut-specific IgE production ${ }^{85}$.

\section{Intestinal epithelial antigen passages}

While food exposure to the skin, particularly in infants, is common, dietary food components (carbohydrates, proteins, lipids, solutes, water) and the resulting digested soluble protein allergens are predominantly absorbed in the SI (duodenum, jejunum, and ileum) and large intestine (colon and rectum $)^{87}$. The tolerogenic inductive sites including organized lymphoid tissues such as the SI draining mesenteric lymph nodes (MLNs) and the specialized immune cell populations including mucosal DCs and Tregs are dominant within this GI compartment, supporting the concept that the SI is key in the establishment of the tolerogenic response and immune homeostasis ${ }^{88,89}$. The mechanism by which the specialized immune cells of the GI tract acquire dietary food antigens is not as well understood. Experimental evidence supports the involvement of several mechanisms in the translocation of food antigens across the SI lumen, including microfold cell-mediated transcytosis, sampling by transepithelial dendrites of mucosal DCs, and paracellular leak ${ }^{90,91}$.

Recently, a role for goblet cells (GCs) was identified in the uptake and translocation of GI luminal antigens across the epithelium and presentation to the immune compartment by a process known as GC antigen passages (GAPs) ${ }^{92}$. GAPs are spatially and temporally regulated and are present in both the SI and the distal colon at steady state ${ }^{92,93}$. In the SI, GAP formation and antigen uptake is initiated around day 18 of life, is activated by acetylcholine (ACh) through a muscarinic type 4 receptor (M4AchR)-dependent process, and is maintained throughout adulthood ${ }^{94}$. SI GAPs are not sensitive to commensal microbiota $^{93,95}$; however, they are sensitive to pathogenic infections such as Salmonella ${ }^{90}$. It is currently postulated that the inhibition of SI GAPs by pathogenic infections is likely a host-dependent response to limit systemic dissemination of pathogenic organisms. Similar to SI GAPs, colonic GAPs are activated by M4AchR-dependent processes; however, colonic GAPs are sensitive to the microbial environment ${ }^{94}$. The tightly regulated anatomical compartmentalization of GAPs in the SI and colon is likely a mechanism whereby the GI epithelium directs luminal antigen sampling to tune immune development and limit pathogenic antigen exposure and development of inappropriate inflammatory responses ${ }^{94,96}$. GAPs appear to deliver GI luminal antigens to LP-antigen-presenting cells such as $\mathrm{CD}_{103}{ }^{+} \mathrm{DCs}^{92}$ and $\mathrm{CX}_{3} \mathrm{CR} 1^{+} \mathrm{DCs}^{92}$ and induce T-cell responses ${ }^{95}$. In the SI, both $\mathrm{CD}_{103^{+}} \mathrm{DCs}$ and $\mathrm{CX}_{3} \mathrm{CR} 1^{+}$DCs are capable of acquiring luminal antigen and inducing $\mathrm{T}$-cell responses; however, the frequency of SI GAPs and $\mathrm{CD}_{103^{+}} \mathrm{DC}$ interactions is more dominant. In contrast, colonic $\mathrm{CX}_{3} \mathrm{CR} 1^{+} \mathrm{DCs}$ appear to be the dominant antigen-presenting cell that interact with colonic GAPs and acquire luminal antigens, including commensal bacteria ${ }^{95}$. These studies lend nicely to the concept that SI GAPs transfer SI soluble protein antigens predominantly to $\mathrm{CD}_{103}{ }^{+} \mathrm{DCs}$, which contribute to the development of oral tolerance, whereas LI colonic GAPs predominantly interact with $\mathrm{CX}_{3} \mathrm{CR}^{+}$DCs and transfer microbial antigens and macromolecules for the induction of antigen-specific tolerance to gut bacteria ${ }^{94}$.

We recently showed that SI GAPs participate in dietary protein antigen uptake ${ }^{97}$. We showed that in naïve mice, clinically relevant food allergens are acquired by SI GC $\left(\mathrm{MUC}^{+}\right)$cells. Surprisingly, under food allergic conditions, the SI antigen passage repertoire and frequency were dysregulated. Moreover, the frequency of SI GAPs was significantly greater in the food-allergic mice than in the naïve WT BALB/c mice at steady state. Furthermore, we identified MUC2- Rh-Dex ${ }^{+}$cells in the SI villus, which were identified as antigen passaging enteroendocrine and Paneth cells, in the SI of food-allergic mice $^{91}$. These data suggest that under food-allergic conditions, multiple intestinal secretory cell lineages within the SI can acquire and channel food antigens from the apical to basolateral side, which we defined as SI secretory epithelial cell antigen passages (SAPs) ${ }^{91}$. Mechanistic analyses revealed that SI SAPs were predominantly regulated by the Th2 cytokine IL-13 and not IL-4, via a direct IL-4R $\alpha$-STAT6-independent PI3KCD38-cADPR-dependent process and rapidly channel food antigens directly to $\mathrm{FceR}^{+}{\mathrm{c}-\mathrm{Kit}^{+}}^{\mathrm{ST}} 2^{\text {high }}$ mucosal $\mathrm{MCs}$ in food-allergic mice. Notably, pharmacological or genetic blockade of IL-13-driven SAP formation protected mice against a food-induced anaphylactic reaction ${ }^{91}$. Importantly, using a human intestinal organoids (HIOs) model system, we were able to show that both GAPs and SAPs were conserved in human tissue. Collectively, these studies reveal that the foodsensitized state and heightened levels of type- 2 cytokines can lead to the reprogramming of the cellular patterning of intestinal 
epithelial antigen passages and presentation of dietary antigens to different immune compartments. The precise mechanism by which food allergens stimulate SAP formation and passage of antigens to mucosal $\mathrm{MCs}$ is currently unknown and under further investigation.

\section{Molecular mechanisms of food-induced anaphylaxis severity}

Food-induced anaphylaxis leads to a number of symptoms that can affect one or more target organs ${ }^{5,98,99}$. Involvement of either the cardiovascular or the respiratory system constitutes a severe food allergic reaction ${ }^{5,98}$, and this may be a result of basophil- and MC-derived mediators inducing pulmonary venous vasodilatation and fluid extravasation, leading to the respiratory and cardiovascular collapse associated with the severe, life-threatening anaphylactic phenotype ${ }^{100}$. It is uncertain which cellular and molecular pathways directly contribute to this anaphylaxis phenotype. Higher levels of IL-4 and histamine have been reported in the serum of human patients with severe anaphylaxis ${ }^{101}$, indicating that these molecules may be involved in the expression of the severe disease phenotype. Recently, our group identified an important role for IL-4 in amplifying histamine-induced anaphylaxis responses ${ }^{102}$. Employing both active and passive models of IgE-mediated anaphylaxis, we showed that IL-4 exacerbated histamineinduced hypovolemic shock in mice and that this was dependent on vascular endothelial (VE) expression of IL-4R $\alpha$. Mechanistic analyses revealed that IL-4 and histamine induced ABL1 activation in human VE cells and that VE barrier dysfunction was ABL1 dependent. The development of severe IgE-mediated hypovolemia and shock required VE-restricted ABL1 expression. Treatment of mice with a history of foodinduced anaphylaxis with the ABL kinase inhibitor imatinib protected the mice from severe IgE-mediated anaphylaxis. Collectively, IL-4 amplifies IgE- and histamine-induced VE dysfunction, fluid extravasation, and the severity of anaphylaxis

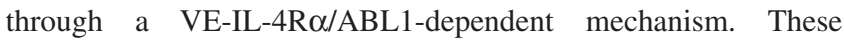
findings suggest that ABL1 kinase could be a potential therapeutic target for preventing IgE-mediated anaphylaxis. Considering that tyrosine kinase inhibitors (TKIs), such as imatinib, can target both endothelial cells and c-Kit-mediated MC development and survival, targeting ABL1 could provide a "double hit" to potently attenuate IgE-mediated responses. Interestingly, a recent study showed imatinib to be efficacious in severe refractory asthma patients, with decreased MC numbers and asthma symptoms ${ }^{103}$.

\section{Advances in food allergy treatment}

Epinephrine remains the first line of acute treatment for food-induced anaphylactic reactions, acting through the $\alpha 1 / \beta 1 / \beta 2$-adrenergic receptors to temper the pathophysiologic response $^{2-4,7}$. Along with epinephrine, H1- and H2-antihistamines are also used to treat anaphylactic reactions ${ }^{104}$, and omalizumab, an anti-IgE monoclonal antibody, has been shown to be effective in patients with idiopathic anaphylaxis with $\operatorname{IgE}$ involvement ${ }^{2,105}$. Recently, there has been increasing attention in the usage of oral immunotherapy (OIT) as a new approach to treating IgE-mediated food allergies. OIT involves oral exposure of gradual increasing doses of the eliciting allergen under close medical supervision, with the starting dose lower than what typically may trigger an allergic reaction and performing dose escalations (approximately every 2 weeks) until one achieves a maintenance dose (typically about 4-6 months), and this maintenance dose is continued indefinitely. Several clinical trials have demonstrated good safety profiles, decreased allergen-specific IgE, and effectiveness in raising the threshold of allergen needed to trigger an allergic reaction ${ }^{106-110}$.

In an exciting development for peanut-allergic individuals, AR101 (Palforzia), an investigational peanut protein biologic, has recently been approved for peanut OIT treatment to reduce allergic reaction incidence and severity in peanut-allergic patients aged 4-17 years old. In the Peanut Allergy Oral Immunotherapy Study of AR101 for Desensitization (PALISADE NCT02635776), a randomized, double-blind, placebocontrolled, phase III trial, OIT using AR101 significantly lowered reactivity and decreased severity of symptoms in patients 4-17 years of age $^{107}$. A total of $67 \%$ of patients who received AR101 were able to tolerate the $600 \mathrm{mg}$ exit challenge dose without any dose-limiting symptoms, as compared to $4 \%$ of the placebo group. At the exit food challenge, $25 \%$ and $5 \%$ of patients treated with AR101 showed moderate and severe symptoms, respectively, while 59\% and $11 \%$ of those receiving placebo showed moderate and severe symptoms, respectively ${ }^{107}$. While these findings are very encouraging, there are several limitations in this study, preventing broader applicability. Firstly, patients 18-55 years of age upon treatment with AR101 did not show significant protection at exit food challenge. Furthermore, the study selected only patients who showed dose-limiting symptoms to up to $100 \mathrm{mg}$ of peanut, thus excluding approximately $50 \%$ of peanutallergic patients ${ }^{107,111}$. Finally, AR101 efficacy or safety could not be established in patients with severe co-morbidities, since patients with severe or poorly managed asthma were excluded because of safety considerations. Some of these limitations are being addressed in ongoing peanut OIT trials: NCT03201003, NCT02993107, and NCT03292484. Other questions concerning optimization of OIT, such as optimal dose and duration of maintenance and the sustainability of this state of desensitization or unresponsiveness, are also currently under investigation.

Supplementation with probiotics for the prevention or treatment of food allergy has also been an area of active research. Previous studies have reported that supplementation of extensively hydrolyzed casein with Lactobacillus rhamnosus ${ }^{12,113}$, but not Lactobacillus casei and Bifidobacterium lactis $^{114}$, has been shown to accelerate tolerance induction in cow's milkallergic individuals. Lactobacillus rhamnosus supplementation is known to promote the expansion of tolerogenic butyrate-producing bacterial strains (e.g. Lachnospiraceae and Ruminococcaceae $)^{115}$, leading to speculation that probiotics can expand tolerance-promoting microbes and drive immunological tolerance to foods. A randomized placebo-controlled trial designed to evaluate the effect of coadministration of a probiotic and peanut OIT (PPOIT) demonstrated that PPOIT was effective in inducing possible sustained unresponsiveness and immune 
changes in peanut-allergic children ${ }^{116}$. A 4-year follow up study to assess long-term outcomes revealed that PPOIT provided long-lasting clinical benefit and persistent suppression of the allergic immune response to peanut ${ }^{117}$.

Despite the clinical success of OIT achieving average desensitization rates of $80-85 \%$, the underlying cellular and molecular processes that mediate OIT desensitization are not yet fully elucidated ${ }^{14,118}$. Rush desensitization (DS), a clinical protocol often used to manage drug allergies, has been shown to rapidly render allergic individuals temporarily hyporesponsive to the antigen and permits the individuals to tolerate eliciting drug exposure. Similar to OIT, DS involves exposure of an individual to increasing doses of the eliciting antigen; however, DS is over a short interval of time, typically with minutes or hours between doses. Oral DS has been successfully used to allow patients to tolerate the first dose of immunotherapy regimens for certain food allergies ${ }^{119,120}$. The temporary hyporesponsiveness to the eliciting antigen is thought to be mediated by MC desensitization, where repeated low-dose antigen exposure causes gradual and limiting release of MC-derived mediators until achieving cell exhaustion and mediator depletion, leading to a diminished IgE-FceRIdependent MC response. Anecdotal clinical evidence demonstrating that short-term discontinuation of OIT treatment can lead to responsiveness in some tolerant OIT individuals and the observed reduced allergen-specific MC and basophil degranulation in individuals during OIT in principal support the concept of MC sensitization involvement ${ }^{121,122}$.

An alternative hypothesis is that OIT desensitization is mediated by the development of allergen-specific IL- $10^{+}$and TGF- $\beta^{+}$ Tregs or exhaustion/deletion of memory allergen-specific $\mathrm{CD}^{+}$ Th2 cells, leading to immunological and clinical tolerance ${ }^{123-125}$. A recent study revealed that patients who underwent OIT had increased frequency of peanut-specific Tregs. Interestingly, the patients with sustained unresponsiveness had significant hypomethylation at FoxP3 $\mathrm{CpG}$ sites in antigen-induced Foxp3 ${ }^{+}$ Tregs, while patients unable to maintain sustained unresponsiveness had hypermethylation, suggesting that epigenetic changes made during or after OIT could contribute to OIT-induced sustained unresponsiveness ${ }^{126}$. In mice, milk OIT increased SI levels of tolerogenic cytokines IL-10 and TGF- $\beta^{125}$. Furthermore, GATA3 hypermethylation in $\mathrm{CD} 4^{+} \mathrm{Th} 2$ cells and FOXP3 hypomethylation in Tregs have been observed in epicutaneous immunotherapy-treated mice ${ }^{127}$. Recently, Wambre et al. identified a terminally differentiated allergen-specific memory Th2 cell population, termed TH2A cells ${ }^{128}$. TH2A cells co-express CRTH2, CD49d, and CD161 and are potent producers of the cytokines IL-5 and IL-9 ${ }^{128}$. Interestingly, OIT in peanut-allergic individuals significantly decreased the frequency of $\mathrm{TH} 2 \mathrm{~A}$ cells, suggesting that OIT may induce exhaustion/deletion of memory allergen-specific Th2 cells ${ }^{128}$. Understanding the immunological processes that drive OIT desensitization and clinical tolerance will be critical for the development and optimization of OIT biologics and protocols.

\section{Summary}

It is becoming increasingly clear that a dynamic and complex interplay among dietary components, environmental stimuli, microbiota, and host immunity is required to develop and sustain the unresponsiveness to dietary food antigens. Dysregulation of these key processes leads to a breakdown of oral tolerance and allergic sensitization. A deeper understanding of the molecular and cellular mechanisms that underlie the breakdown of tolerance will be critical in guiding precision medicine approaches and directing better diagnosis, management, and safer and more efficacious treatment options for patients of food allergy and anaphylaxis.
1. Simons FER, Ardusso LR, Bilò MB, et al.: International consensus on (ICON) anaphylaxis. World Allergy Organ J. 2014; 7(1): 9 PubMed Abstract | Publisher Full Text | Free Full Text

2. Jimenez-Rodriguez TW, Garcia-Neuer M, Alenazy LA, et al.: Anaphylaxis in the 21st century: Phenotypes, endotypes, and biomarkers. J Asthma Allergy. 2018; 11: 121-42.

PubMed Abstract | Publisher Full Text | Free Full Text | Faculty Opinions Recommendation

3. Simons FER, Ardusso LRF, Bilò MB, et al.: 2012 Update: World Allergy Organization Guidelines for the assessment and management of anaphylaxis. Curr Opin Allergy Clin Immunol. 2012; 12(4): 389-99. PubMed Abstract | Publisher Full Text

4. Muraro A, Roberts G, Worm M, et al:: Anaphylaxis: Guidelines from the European Academy of Allergy and Clinical Immunology. Allergy. 2014; 69(8): 1026-45.

PubMed Abstract | Publisher Full Text

5. Sampson HA, Muñoz-Furlong A, Campbell RL, et al:: Second Symposium on the Definition and Management of Anaphylaxis: Summary Report--Second National Institute of Allergy and Infectious Disease/Food Allergy and Anaphylaxis Network Symposium. Ann Emerg Med. 2006; 47(4): 373-80. PubMed Abstract | Publisher Full Text

6. Muraro A, Lemanske RF Jr, Castells M, et al.: Precision medicine in allergic disease-food allergy, drug allergy, and anaphylaxis-PRACTALL document of the European Academy of Allergy and Clinical Immunology and the American Academy of Allergy, Asthma and Immunology. Allergy. 2017; 72(7): 1006-21. PubMed Abstract | Publisher Full Text | Faculty Opinions Recommendation

7. Castells $M$ : Diagnosis and management of anaphylaxis in precision medicine. J Allergy Clin Immunol. 2017; 140(2): 321-33. PubMed Abstract | Publisher Full Text

8. Pabst O, Mowat AM: Oral tolerance to food protein. Mucosal Immunol. 2012; 5(3): 232-9.

PubMed Abstract | Publisher Full Text | Free Full Text

9. Commins SP: Mechanisms of Oral Tolerance. Pediatr Clin North Am. 2015; 62(6): 1523-9.

PubMed Abstract | Publisher Full Text | Free Full Text

10. Yu W, Freeland DMH, Nadeau KC: Food allergy: Immune mechanisms, diagnosis and immunotherapy. Nat Rev Immunol. 2016; 16(12): 751-65. PubMed Abstract | Publisher Full Text | Free Full Text

11. Esterházy D, Canesso MCC, Mesin L, et al.: Compartmentalized gut lymph node drainage dictates adaptive immune responses. Nature. 2019; 569(7754): 126-30.

PubMed Abstract | Publisher Full Text | Free Full Text | Faculty Opinions Recommendation

12. Coombes $\mathrm{JL}$, Maloy $\mathrm{KJ}$ : Control of intestinal homeostasis by regulatory $\mathrm{T}$ cells 
and dendritic cells. Semin Immunol. 2007; 19(2): 116-26. PubMed Abstract | Publisher Full Text

13. S Sun CM, Hall JA, Blank RB, et al:: Small intestine lamina propria dendritic cells promote de novo generation of Foxp3 $\mathrm{T}$ reg cells via retinoic acid. $J$ Exp Med. 2007; 204(8): 1775-85.

PubMed Abstract | Publisher Full Text | Free Full Text

Faculty Opinions Recommendation

14. Chinthrajah RS, Hernandez JD, Boyd SD, et al.: Molecular and cellular mechanisms of food allergy and food tolerance. J Allergy Clin Immunol. 2016; 137(4): 984-97.

PubMed Abstract | Publisher Full Text | Free Full Text

15. Coombes JL, Siddiqui KRR, Arancibia-Cárcamo CV, et al:: A functionally specialized population of mucosal $\mathrm{CD}_{103^{+}} \mathrm{DCs}$ induces Foxp $3^{+}$regulatory $\mathrm{T}$ cells via a TGF- $\beta$ - and retinoic acid-dependent mechanism. J Exp Med. 2007; 204(5): 1757-64.

PubMed Abstract | Publisher Full Text | Free Full Text

16. Hadis $\mathrm{U}$, Wahl $\mathrm{B}, \mathrm{Schulz} \mathrm{O}$, et al.: Intestinal tolerance requires gut homing and expansion of $\mathrm{FoxP3}^{+}$regulatory T cells in the lamina propria. Immunity. 2011; 34(2): 237-46.

PubMed Abstract | Publisher Full Text

17. Noval Rivas M, Burton OT, Oettgen HC, et al.: IL-4 production by group 2 innate lymphoid cells promotes food allergy by blocking regulatory T-cell function. J Allergy Clin Immunol. 2016; 138(3): 801-811.e9. PubMed Abstract | Publisher Full Text | Free Full Text

18. Curotto de Lafaille MA, Kutchukhidze N, Shen S, et al:: Adaptive Foxp3 ${ }^{+}$ regulatory $\mathrm{T}$ cell-dependent and -independent control of allergic inflammation. Immunity. 2008; 29(1): 114-26.

PubMed Abstract | Publisher Full Text

19. Tordesillas L, Mondoulet L, Blazquez AB, et al.: Epicutaneous immunotherapy induces gastrointestinal LAP+ regulatory $\mathrm{T}$ cells and prevents food-induced anaphylaxis. J Allergy Clin Immunol. 2017; 139(1): 189-201.e4. PubMed Abstract | Publisher Full Text | Free Full Text | Faculty Opinions Recommendation

20. Prince BT, Devonshire AL, Erickson KA, et al.: Regulatory T-cell populations in children are affected by age and food allergy diagnosis. J Allergy Clin Immunol. 2017; 140(4): 1194-1196.e16.

PubMed Abstract | Publisher Full Text | Free Full Text

21. Karlsson MR, Rugtveit J, Brandtzaeg P: Allergen-responsive CD4 ${ }^{+} \mathrm{CD}_{25}{ }^{+}$ Regulatory T Cells in Children who Have Outgrown Cow's Milk Allergy. J Exp Med. 2004; 199(12): 1679-88.

PubMed Abstract | Publisher Full Text | Free Full Text

22. Mortha A, Chudnovskiy A, Hashimoto D, et al:: Microbiota-dependent crosstalk between macrophages and ILC3 promotes intestinal homeostasis. Science. 2014; 343(6178): 1249288

PubMed Abstract | Publisher Full Text | Free Full Text

Faculty Opinions Recommendation

23. Stefka AT, Feehley $\mathrm{T}$, Tripathi $\mathrm{P}$, et al:: Commensal bacteria protect agains food allergen sensitization. Proc Natl Acad Sci U S A. 2014; 111(36): 13145-50. PubMed Abstract | Publisher Full Text | Free Full Text | Faculty Opinions Recommendation

24. Satitsuksanoa P, Jansen K, Głobińska A, et al: Regulatory Immune Mechanisms in Tolerance to Food Allergy. Front Immunol. 2018. 9. 2939. PubMed Abstract | Publisher Full Text | Free Full Text | Faculty Opinions Recommendation

25. Kim AR, Kim HS, Kim DK, et al:: Mesenteric IL-10-producing CD5+ regulatory $B$ cells suppress cow's milk casein-induced allergic responses in mice. $S c i$ Rep. 2016; 6: 827.

PubMed Abstract | Publisher Full Text | Free Full Text |

Faculty Opinions Recommendation

26. Esterházy D, Loschko J, London M, et al:: Classical dendritic cells are required for dietary antigen-mediated induction of peripheral $T(\mathrm{reg})$ cells and tolerance. Nat Immunol. 2016; 17(5): 545-55.

PubMed Abstract | Publisher Full Text | Free Full Text |

Faculty Opinions Recommendation

27. Cohnmacht C, Park JH, Cording S, et al:: MUCOSAL IMMUNOLOGY. The microbiota regulates type 2 immunity through ROR $\mathbf{t}^{+} \mathbf{T}$ cells. Science. 2015 349(6251): 989-93.

PubMed Abstract | Publisher Full Text | Faculty Opinions Recommendation

28. Cefik E, Geva-Zatorsky N, Oh S, et al:: MUCOSAL IMMUNOLOGY. Individual intestinal symbionts induce a distinct population of $\mathrm{ROR} \gamma^{+}$regulatory $\mathrm{T}$ cells. Science. 2015; 349(6251): 993-7.

PubMed Abstract | Publisher Full Text | Free Full Text |

Faculty Opinions Recommendation

29. Barcik W, Untersmayr E, Pali-Schöll I, et al.: Influence of microbiome and diet on immune responses in food allergy models. Drug Discov Today Dis Models. 2015; 17-18: 71-80.

PubMed Abstract | Publisher Full Text | Free Full Text

30. Khodoun MV, Tomar S, Tocker JE, et al:: Prevention of food allergy development and suppression of established food allergy by neutralization of thymic stromal lymphopoietin, IL-25, and IL-33. J Allergy Clin Immunol. 2018; 141(1): 171-179.e1. PubMed Abstract | Publisher Full Text
31. Li J, Wang $Y$, Tang L, et al.: Dietary medium-chain triglycerides promote ora allergic sensitization and orally induced anaphylaxis to peanut protein in mice. J Allergy Clin Immunol. 2013; 131(2): 442-50.

PubMed Abstract | Publisher Full Text | Free Full Text

32. Samavedam UK, Khodoun M, Wu D, et al.: Saturated fatty acids promote allergic (Th2) cytokine responses by activation of unfolded protein response (UPR) and ER stress. J Immunol. 2016; 196(Supplement 1): 123.9.

Reference Source

33. Samavedam UK, Morris SC, Khodoun M, et al: Saturated fat-induced food allergy: A paradigm for unfolded protein response (UPR)-mediated allergic inflammation. J Immunol. 2018; 200(1 Supplement): 104.14 Reference Source

34. Xie J, Lotoski LC, Chooniedass R, et al.: Elevated antigen-driven IL-9 responses are prominent in peanut allergic humans. PLoS One. 2012; 7(10): e45377. PubMed Abstract | Publisher Full Text | Free Full Text

35. Brough HA, Cousins DJ, Munteanu A, et al.: IL-9 is a key component of memory TH cell peanut-specific responses from children with peanut allergy. $J$ Allergy Clin Immunol. 2014; 134(6): 1329-1338.e10.

PubMed Abstract | Publisher Full Text

36. Blázquez $A B$, Berin MC: Gastrointestinal Dendritic Cells Promote Th2 Skewing via OX40L. J Immunol. 2008; 180(7): 4441-50. PubMed Abstract | Publisher Full Text

37. He SH, Liu ZQ, Chen X, et al.: IL-9+ IL-10+ T cells link immediate allergic response to late phase reaction. Clin Exp Immunol. 2011; 165(1): 29-37. PubMed Abstract | Publisher Full Text | Free Full Text

38. Asrat $\mathrm{S}$, Kaur N, Liu X, et al:: Chronic allergen exposure drives accumulation of long-lived IgE plasma cells in the bone marrow, giving rise to serological memory. Sci Immunol. 2020; 5(43): eaav8402.

PubMed Abstract | Publisher Full Text | Faculty Opinions Recommendation

39. Talay $\mathrm{O}$, Yan $\mathrm{D}$, Brightbill $\mathrm{HD}$, et al.: Ig $\mathrm{E}^{+}$memory $\mathrm{B}$ cells and plasma cells generated through a germinal-center pathway. Nat Immunol. 2012; 13(4): 396-404. PubMed Abstract | Publisher Full Text

40. Hoh RA, Joshi SA, Lee JY, et al:: Origins and clonal convergence of gastrointestinal lgE ${ }^{+}$B cells in human peanut allergy. Sci Immunol. 2020; 5(45): eaay420

PubMed Abstract | Publisher Full Text | Faculty Opinions Recommendation

41. Chen CY, Lee JB, Liu B, et al.: Induction of Interleukin-9-Producing Mucosal Mast Cells Promotes Susceptibility to IgE-Mediated Experimental Food Allergy. Immunity. 2015; 43(4): 788-802.

PubMed Abstract | Publisher Full Text | Free Full Text |

Faculty Opinions Recommendation

42. Osterfeld $\mathrm{H}$, Ahrens $\mathrm{R}$, Strait $\mathrm{R}$, et al.: Differential roles for the IL-9/L-9 recepto $\alpha$-chain pathway in systemic and oral antigen-induced anaphylaxis. $J$ Allergy Clin Immunol. 2010; 125(2): 469-476.e2.

PubMed Abstract | Publisher Full Text | Free Full Text

43. Ahrens $\mathrm{R}$, Osterfeld $\mathrm{H}, \mathrm{Wu} \mathrm{D}$, et al:: Intestinal mast cell levels control severity of oral antigen-induced anaphylaxis in mice. Am J Pathol. 2012; 180(4): 1535-46. PubMed Abstract | Publisher Full Text | Free Full Text

44. Sicherer SH, Sampson HA: Food Allergy: Recent Advances in Pathophysiology and Treatment. Annu Rev Med. 2009; 60: 261-77. PubMed Abstract | Publisher Full Text

45. Renz H, Allen KJ, Sicherer SH, et al.: Food allergy. Nat Rev Dis Primers. 2018; 4: 17098.

PubMed Abstract | Publisher Full Text | Faculty Opinions Recommendation

46. Zhao W, Ho HE, Bunyavanich S: The gut microbiome in food allergy. Ann Allergy Asthma Immunol. 2019; 122(3): 276-82.

PubMed Abstract | Publisher Full Text | Free Full Text |

Faculty Opinions Recommendation

47. Noval Rivas M, Burton OT, Wise P, et al:: A microbiota signature associated with experimental food allergy promotes allergic sensitization and anaphylaxis. J Allergy Clin Immunol. 2013; 131(1): 201-12. PubMed Abstract | Publisher Full Text | Free Full Text | Faculty Opinions Recommendation

48. Iweala OI, Nagler CR: The Microbiome and Food Allergy. Annu Rev Immunol. 2019; 37: 377-403. PubMed Abstract | Publisher Full Tex

49. Plunkett $\mathrm{CH}$, Nagler $\mathrm{CR}$ : The Influence of the Microbiome on Allergic Sensitization to Food. J Immunol. 2017; 198(2): 581-9. PubMed Abstract | Publisher Full Text | Free Full Text | Faculty Opinions Recommendation

50. Kemter AM, Nagler CR: Influences on allergic mechanisms through gut, lung, and skin microbiome exposures. J Clin Invest. 2019; 129(4): 1483-92. PubMed Abstract | Publisher Full Text | Free Full Text

51. Bunyavanich S, Shen N, Grishin A, et al:: Early-life gut microbiome composition and milk allergy resolution. J Allergy Clin Immunol. 2016; 138(4): 1122-30. PubMed Abstract | Publisher Full Text | Free Full Text

52. Hua X, Goedert JJ, Pu A, et al:: Allergy associations with the adult fecal microbiota: Analysis of the American Gut Project. EBioMedicine. 2016; 3: 172-9. PubMed Abstract | Publisher Full Text | Free Full Text

53. Azad MB, Konya T, Guttman DS, et al.: Infant gut microbiota and food 
sensitization: Associations in the first year of life. Clin Exp Allergy. 2015; 45(3): $632-43$

PubMed Abstract | Publisher Full Text

54. Feehley $\mathrm{T}$, Plunkett $\mathrm{CH}$, Bao R, et al.: Healthy infants harbor intestinal bacteria that protect against food allergy. Nat Med. 2019; 25(3): 448-53. PubMed Abstract | Publisher Full Text | Free Full Text |

Faculty Opinions Recommendation

55. Berni Canani R, Gilbert JA, Nagler CR: The role of the commensal microbiota in the regulation of tolerance to dietary allergens. Curr Opin Allergy Clin Immunol. 2015; 15(3): 243-9.

PubMed Abstract | Publisher Full Text | Free Full Text

56. Cao S, Feehley TJ, Nagler CR: The role of commensal bacteria in the regulation of sensitization to food allergens. FEBS Lett. 2014; 588(22): 4258-66. PubMed Abstract | Publisher Full Text | Free Full Text

57. Konieczna $\mathrm{P}$, Groeger $\mathrm{D}$, Ziegler $\mathrm{M}$, et al:: Bifidobacterium infantis $\mathbf{3 5 6 2 4}$ administration induces Foxp3 $\mathrm{T}$ regulatory cells in human peripheral blood: Potential role for myeloid and plasmacytoid dendritic cells. Gut. 2012; 61(3) 354-66.

PubMed Abstract | Publisher Full Text

58. Atarashi K, Tanoue T, Oshima K, et al.: Treg induction by a rationally selected mixture of Clostridia strains from the human microbiota. Nature. 2013; 500(7461): 232-6.

PubMed Abstract | Publisher Full Text | Faculty Opinions Recommendation

59. Macia L, Tan J, Vieira AT, et al:: Metabolite-sensing receptors GPR43 and GPR109A facilitate dietary fibre-induced gut homeostasis through regulation of the inflammasome. Nat Commun. 2015; 6: 6734

PubMed Abstract | Publisher Full Text

60. Singh N, Gurav A, Sivaprakasam S, et al.: Activation of Gpr109a, Receptor for Niacin and the Commensal Metabolite Butyrate, Suppresses Colonic Inflammation and Carcinogenesis. Immunity. 2014; 40(1): 128-39. PubMed Abstract | Publisher Full Text | Free Full Text

61. Arpaia N, Campbell C, Fan X, et al.: Metabolites produced by commensal bacteria promote peripheral regulatory T-cell generation. Nature. 2013; 504(7480): 451-5.

PubMed Abstract | Publisher Full Text | Free Full Text

62. Furusawa Y, Obata Y, Fukuda S, et al.: Commensal microbe-derived butyrate induces the differentiation of colonic regulatory T cells. Nature. 2013 504(7480): 446-50.

PubMed Abstract | Publisher Full Text | Faculty Opinions Recommendation

63. C Smith PM, Howitt MR, Panikov N, et al:: The microbial metabolites, shortchain fatty acids, regulate colonic Treg cell homeostasis. Science. 2013; 341(6145): 569-73

PubMed Abstract | Publisher Full Text | Free Full Text

Faculty Opinions Recommendation

64. Mowat AM: Anatomical basis of tolerance and immunity to intestinal antigens. Nat Rev Immunol. 2003; 3(4): 331-41.

PubMed Abstract | Publisher Full Text

65. Dubois B, Goubier A, Joubert G, et al:: Oral tolerance and regulation of mucosa immunity. Cell Mol Life Sci. 2005; 62(12): 1322-32.

PubMed Abstract | Publisher Full Text

66. Fox AT, Sasieni P, Du Toit G, et al.: Household peanut consumption as a risk factor for the development of peanut allergy. J Allergy Clin Immunol. 2009; 123(2): 417-23.

PubMed Abstract | Publisher Full Text

67. Brough HA, Nadeau KC, Sindher SB, et al.: Epicutaneous sensitization in the development of food allergy: What is the evidence and how can this be prevented? Allergy. 2020

PubMed Abstract | Publisher Full Text | Faculty Opinions Recommendation

68. Drislane $C$, Irvine AD: The role of filaggrin in atopic dermatitis and allergic disease. Ann Allergy Asthma Immunol. 2020; 124(1): 36-43.

PubMed Abstract | Publisher Full Text | Faculty Opinions Recommendation

69. Graham F, Eigenmann PA: Atopic dermatitis and its relation to food allergy. Curr Opin Allergy Clin Immunol. 2020; 20(3): 305-10.

PubMed Abstract | Publisher Full Text | Faculty Opinions Recommendation

70. Milner JD: Primary Atopic Disorders. Annu Rev Immunol. 2020; 38: 785-808. PubMed Abstract | Publisher Full Text | Faculty Opinions Recommendation

71. Schmiechen ZC, Weissler KA, Frischmeyer-Guerrerio PA: Recent developments in understanding the mechanisms of food allergy. Curr Opin Pediatr. 2019; 31(6): 807-14.

PubMed Abstract | Publisher Full Text | Free Full Text |

Faculty Opinions Recommendation

72. Li M: Current evidence of epidermal barrier dysfunction and thymic stromal lymphopoietin in the atopic march. Eur Respir Rev. 2014; 23(133): 292-8. PubMed Abstract | Publisher Full Text

73. Bin L, Leung DYM: Genetic and epigenetic studies of atopic dermatitis. Allergy Asthma Clin Immunol. 2016; 12: 52.

PubMed Abstract | Publisher Full Text | Free Full Text

74. Kim BE, Leung DYM: Significance of Skin Barrier Dysfunction in Atopic
Dermatitis. Allergy Asthma Immunol Res. 2018; 10(3): 207-15

PubMed Abstract | Publisher Full Text | Free Full Text |

Faculty Opinions Recommendation

75. Kelleher MM, Dunn-Galvin A, Gray C, et al:: Skin barrier impairment at birth predicts food allergy at 2 years of age. J Allergy Clin Immunol. 2016; 137(4): 1111-1116.e8.

PubMed Abstract | Publisher Full Text

76. Carlsten C, Dimich-Ward H, Ferguson A, et al:: Atopic dermatitis in a high-risk cohort: Natural history, associated allergic outcomes, and risk factors. Ann Allergy Asthma Immunol. 2013; 110(1): 24-8.

PubMed Abstract | Publisher Full Text

77. Brown SJ, Asai Y, Cordell HJ, et al.: Loss-of-function variants in the filaggrin gene are a significant risk factor for peanut allergy. J Allergy Clin Immunol. 2011; 127(3): 661-7.

PubMed Abstract | Publisher Full Text | Free Full Text |

Faculty Opinions Recommendation

78. Asai $Y$, Greenwood C, Hull PR, et al:: Filaggrin gene mutation associations with peanut allergy persist despite variations in peanut allergy diagnostic criteria or asthma status. J Allergy Clin Immunol. 2013; 132(1): 239-42. PubMed Abstract | Publisher Full Text | Free Full Text

79. Eigenmann PA, Sicherer SH, Borkowski TA, et al:: Prevalence of IgE-mediated food allergy among children with atopic dermatitis. Pediatrics. 1998; 101(3): E8. PubMed Abstract | Publisher Full Text

80. Walker MT, Green JE, Ferrie RP, et al:: Mechanism for initiation of food allergy: Dependence on skin barrier mutations and environmental allergen costimulation. J Allergy Clin Immunol. 2018; 141(5): 1711-1725.e9.

PubMed Abstract | Publisher Full Text | Free Full Text | Faculty Opinions Recommendation

81. Leyva-Castillo J-M, Galand C, Kam C, et al:: Mechanical Skin Injury Promotes Food Anaphylaxis by Driving Intestinal Mast Cell Expansion. Immunity. 2019; 50(5): 1262-1275.e4

PubMed Abstract | Publisher Full Text | Free Full Text |

Faculty Opinions Recommendation

82. Noti M, Kim BS, Siracusa MC, et al:: Exposure to food allergens through inflamed skin promotes intestinal food allergy through the thymic stromal lymphopoietin-basophil axis. J Allergy Clin Immunol. 2014; 133(5): 1390-9, 1399.e1. PubMed Abstract | Publisher Full Text | Free Full Text | Faculty Opinions Recommendation

83. Kawasaki $\mathrm{A}$, Ito $\mathrm{N}$, Murai $\mathrm{H}$, et al:: Skin inflammation exacerbates food allergy symptoms in epicutaneously sensitized mice. Allergy. 2018; 73(6): 1313-21. PubMed Abstract | Publisher Full Text

84. Hussain M, Borcard L, Walsh KP, et al:: Basophil-derived IL-4 promotes epicutaneous antigen sensitization concomitant with the development of food allergy. J Allergy Clin Immunol. 2018; 141(1): 223-234.e5.

PubMed Abstract | Publisher Full Text | Faculty Opinions Recommendation

85. S Smeekens JM, Immormino RM, Balogh PA, et al:: Indoor dust acts as an adjuvant to promote sensitization to peanut through the airway. Clin Exp Allergy. 2019; 49(11): 1500-11.

PubMed Abstract | Publisher Full Text | Free Full Text

Faculty Opinions Recommendation

86. Dolence JJ, Kobayashi T, lijima K, et al:: Airway exposure initiates peanut allergy by involving the IL-1 pathway and T follicular helper cells in mice. J Allergy Clin Immunol. 2018; 142(4): 1144-1158.e8

PubMed Abstract | Publisher Full Text | Free Full Text |

Faculty Opinions Recommendation

87. Kiela PR, Ghishan FK: Physiology of Intestinal Absorption and Secretion. Best Pract Res Clin Gastroenterol. 2016; 30(2): 145-59.

PubMed Abstract | Publisher Full Text | Free Full Text

88. Hamad A, Burks W: Oral tolerance and allergy. Semin Immunol. 2017; 30: 28-35. PubMed Abstract | Publisher Full Text

89. Noh G, Lee JH: Oral tolerance induction for human food allergy. Inflamm Allergy Drug Targets. 2012; 11(2): 131-42. PubMed Abstract | Publisher Full Text

90. Kulkarni DH, McDonald KG, Knoop KA, et al.: Goblet cell associated antigen passages are inhibited during Salmonella typhimurium infection to prevent pathogen dissemination and limit responses to dietary antigens. Mucosal Immunol. 2018; 11(4): 1103-13.

PubMed Abstract | Publisher Full Text | Free Full Text |

Faculty Opinions Recommendation

91. N Noah TK, Knoop KA, McDonald KG, et al.: IL-13-induced intestinal secretory epithelial cell antigen passages are required for IgE-mediated food-induced anaphylaxis. J Allergy Clin Immunol. 2019; 144(4): 1058-1073.e3. PubMed Abstract | Publisher Full Text | Free Full Text | Faculty Opinions Recommendation

92. McDole JR, Wheeler LW, McDonald KG, et al:: Goblet cells deliver luminal antigen to $\mathrm{CD} 103^{+}$dendritic cells in the small intestine. Nature. 2012 483(7389): 345-9.

PubMed Abstract | Publisher Full Text | Free Full Text |

Faculty Opinions Recommendation 
93. Knoop KA, McDonald KG, McCrate S, et al:: Microbial sensing by goblet cells controls immune surveillance of luminal antigens in the colon. Mucosal Immunol. 2015; 8(1): 198-210.

PubMed Abstract | Publisher Full Text | Free Full Text

94. Knoop KA, Gustafsson JK, McDonald KG, et al:: Microbial antigen encounter during a preweaning interval is critical for tolerance to gut bacteria. $\mathrm{Sci}$ Immunol. 2017; 2(18): eaao1314.

PubMed Abstract | Publisher Full Text | Free Full Text

95. Knoop KA, Gustafsson JK, McDonald KG, et al.: Antibiotics promote the sampling of luminal antigens and bacteria via colonic goblet cell associated antigen passages. Gut Microbes. 2017; 8(4): 400-11. PubMed Abstract | Publisher Full Text | Free Full Text

96. Kulkarni DH, Newberry RD: Intestinal Macromolecular Transport Supporting Adaptive Immunity. Cell Mol Gastroenterol Hepatol. 2019; 7(4): 729-37. PubMed Abstract | Publisher Full Text | Free Full Text | Faculty Opinions Recommendation

97. Kulkarni DH, Gustafsson JK, Knoop KA, et al: Goblet cell associated antigen passages support the induction and maintenance of oral tolerance. Mucosal Immunol. 2020; 13(2): 271-82.

PubMed Abstract | Publisher Full Text | Free Full Text

98. Sampson HA, Muñoz-Furlong A, Bock SA, et al:: Symposium on the definition and management of anaphylaxis: Summary report. J Allergy Clin Immunol. 2005; 115(3): 584-91.

PubMed Abstract | Publisher Full Text

99. SampsonHA:Food-inducedanaphylaxis.NovartisFoundSymp.2004;257:161-71; discussion171-6, 207-10, 276-85

PubMed Abstract | Publisher Full Text

100. Silverman HJ, van Hook C, Haponik EF: Hemodynamic changes in human anaphylaxis. Am J Med. 1984; 77(2): 341-4. PubMed Abstract | Publisher Full Text

101. Ogawa Y, Grant JA: Mediators of anaphylaxis. Immunol Allergy Clin North Am. 2007; 27(2): 249-60, vii. PubMed Abstract | Publisher Full Text

102. Yamani $A$, Wu D, Waggoner $L$, et al:: The vascular endothelial specific IL-4 receptor alpha-ABL1 kinase signaling axis regulates the severity of IgE-mediated anaphylactic reactions. J Allergy Clin Immunol. 2018; 142(4): 1159-1172.e5. PubMed Abstract | Publisher Full Text | Free Full Text

103. Cahill KN, Katz HR, Cui J, et al: KIT Inhibition by Imatinib in Patients with Severe Refractory Asthma. N Engl J Med. 2017; 376(20): 1911-20. PubMed Abstract | Publisher Full Text | Free Full Text | Faculty Opinions Recommendation

104. Lieberman $\mathrm{P}$, Nicklas RA, Randolph $\mathrm{C}$, et al:: Anaphylaxis-a practice parameter update 2015. Ann Allergy Asthma Immunol. 2015; 115(5): 341-84. PubMed Abstract | Publisher Full Text

105. Warrier P, Casale TB: Omalizumab in idiopathic anaphylaxis. Ann Allergy Asthma Immunol. 2009; 102(3): 257-8.

PubMed Abstract | Publisher Full Text | Faculty Opinions Recommendation

106. Vickery BP, Berglund JP, Burk CM, et al.: Early oral immunotherapy in peanutallergic preschool children is safe and highly effective. J Allergy Clin Immunol. 2017; 139(1): 173-181.e8.

PubMed Abstract | Publisher Full Text | Free Full Text

107. P PalisaDE Group of Clinical Investigators, Vickery BP, Vereda A, et al:: AR101 Oral Immunotherapy for Peanut Allergy. N Engl J Med. 2018; 379(21): 1991-2001. PubMed Abstract | Publisher Full Text | Faculty Opinions Recommendation

108. Gomez F, Bogas G, Gonzalez M, et al.: The clinical and immunological effects of Pru p 3 sublingual immunotherapy on peach and peanut allergy in patients with systemic reactions. Clin Exp Allergy. 2017; 47(3): 339-50. PubMed Abstract | Publisher Full Text

109. Graham F, Tardio N, Paradis L, et al:: Update on oral immunotherapy for egg allergy. Hum Vaccin Immunother. 2017; 13(10): 2452-61. PubMed Abstract | Publisher Full Text | Free Full Text

110. CBurks AW, Jones SM, Wood RA, et al:: Oral immunotherapy for treatment of egg allergy in children. N Engl J Med. 2012; 367(3): 233-43. PubMed Abstract | Publisher Full Text | Free Full Text Faculty Opinions Recommendation

111. Allen $\mathrm{KJ}$, Remington $\mathrm{BC}$, Baumert JL, et al:: Allergen reference doses for precautionary labeling (VITAL 2.0): Clinical implications. J Allergy Clin Immunol. 2014; 133(1): 156-64 PubMed Abstract | Publisher Full Text
112. Berni Canani R, Nocerino R, Terrin G, et al.: Effect of Lactobacillus GG on tolerance acquisition in infants with cow's milk allergy: A randomized trial. J Allergy Clin Immunol. 2012; 129(2): 580-2, 582.e1-5. PubMed Abstract | Publisher Full Text | Faculty Opinions Recommendation

113. CBerni Canani R, Nocerino R, Terrin G, et al.: Formula Selection for Management of Children with Cow's Milk Allergy Influences the Rate of Acquisition of Tolerance: A Prospective Multicenter Study. J Pediatr. 2013; 163(3): 771-777.e1.

PubMed Abstract | Publisher Full Text | Faculty Opinions Recommendation

114. Hol J, van Leer EHG, Elink Schuurman BEE, et al.: The acquisition of tolerance toward cow's milk through probiotic supplementation: A randomized, controlled trial. J Allergy Clin Immunol. 2008; 121(6): 1448-54. PubMed Abstract | Publisher Full Text

115. Berni Canani R, Sangwan N, Stefka AT, et al:: Lactobacillus rhamnosus GGsupplemented formula expands butyrate-producing bacterial strains in food allergic infants. ISME J. 2016; 10(3): 742-50. PubMed Abstract | Publisher Full Text | Free Full Text

116. Tang MLK, Ponsonby AL, Orsini F, et al.: Administration of a probiotic with peanut oral immunotherapy: A randomized trial. J Allergy Clin Immunol. 2015; 135(3): 737-44.e8

PubMed Abstract | Publisher Full Text

117. Hsiao KC, Ponsonby AL, Axelrad C, et al.: Long-term clinical and immunological effects of probiotic and peanut oral immunotherapy after treatment cessation: 4-year follow-up of a randomised, double-blind, placebo-controlled trial. Lancet Child Adolesc Health. 2017; 1(2): 97-105.

PubMed Abstract | Publisher Full Text

118. Begin P, Chinthrajah RS, Nadeau KC: Oral immunotherapy for the treatment of food allergy. Hum Vaccin Immunother. 2014; 10(8): 2295-302. PubMed Abstract | Publisher Full Text | Free Full Text

119. Pajno GB, Cox L, Caminiti L, et al:: Oral Immunotherapy for Treatment of Immunoglobulin E-Mediated Food Allergy: The Transition to Clinical Practice. Pediatr Allergy Immunol Pulmonol. 2014; 27(2): 42-50. PubMed Abstract | Publisher Full Text | Free Full Text

120. Land MH, Kim EH, Burks AW: Oral desensitization for food hypersensitivity. Immunol Allergy Clin North Am. 2011; 31: 367-76, xi. PubMed Abstract | Publisher Full Text | Free Full Text

121. Rachid R, Umetsu DT: Immunological mechanisms for desensitization and tolerance in food allergy. Semin Immunopathol. 2012; 34(5): 689-702. PubMed Abstract | Publisher Full Text | Free Full Text

122. Narisety SD, Keet CA: Sublingual vs oral immunotherapy for food allergy: Identifying the right approach. Drugs. 2012; 72(15): 1977-89. PubMed Abstract | Publisher Full Text | Free Full Text

123. Sampson HA, O'Mahony L, Burks AW, et al:: Mechanisms of food allergy. J Allergy Clin Immunol. 2018; 141(1): 11-9. PubMed Abstract | Publisher Full Text | Faculty Opinions Recommendation

124. Allam JP, Würtzen PA, Reinartz M, et al.: Phl p 5 resorption in human oral mucosa leads to dose-dependent and time-dependent allergen binding by oral mucosal Langerhans cells, attenuates their maturation, and enhances their migratory and TGF-beta1 and IL-10-producing properties. J Allergy Clin Immunol. 2010; 126(3): 638-45.e1. PubMed Abstract | Publisher Full Text

125. Smaldini PL, Orsini Delgado ML, Fossati CA, et al:: Orally-Induced Intestinal CD4 $\mathrm{CD}^{2} 5^{+} \mathrm{FoxP}^{+}{ }^{+}$Treg Controlled Undesired Responses towards Oral Antigens and Effectively Dampened Food Allergic Reactions. PLoS One. 2015; 10(10): e0141116.

PubMed Abstract | Publisher Full Text | Free Full Text

126. Syed A, Garcia MA, Lyu SC, et al.: Peanut oral immunotherapy results in increased antigen-induced regulatory T-cell function and hypomethylation of forkhead box protein 3 (FOXP3). J Allergy Clin Immunol. 2014; 133(2): 500-10. PubMed Abstract | Publisher Full Text | Free Full Text

127. Mondoulet L, Dioszeghy V, Busato F, et al.: Gata3 hypermethylation and Foxp3 hypomethylation are associated with sustained protection and bystander effect following epicutaneous immunotherapy in peanut-sensitized mice. Allergy. 2018; 74(1): 152-64. PubMed Abstract | Publisher Full Text | Free Full Text | Faculty Opinions Recommendation

128. W Wambre E, Bajzik V, DeLong JH, et al:: A phenotypically and functionally distinct human $\mathrm{T}_{4} 2$ cell subpopulation is associated with allergic disorders. Sci Transl Med. 2017; 9(401): eaam9171. PubMed Abstract | Publisher Full Text | Free Full Text | Faculty Opinions Recommendation 


\section{Open Peer Review}

\section{Current Peer Review Status:}

\section{Editorial Note on the Review Process}

Faculty Reviews are review articles written by the prestigious Members of Faculty Opinions. The articles are commissioned and peer reviewed before publication to ensure that the final, published version is comprehensive and accessible. The reviewers who approved the final version are listed with their names and affiliations.

\section{The reviewers who approved this article are:}

\section{Version 1}

\section{Michael D Kulis}

Department of Pediatrics, University of North Carolina at Chapel Hill, Chapel Hill, NC, USA

Competing Interests: No competing interests were disclosed.

\section{Hans Oettgen}

Division of Immunology, Boston Children's Hospital, Boston, MA, USA

Competing Interests: No competing interests were disclosed.

The benefits of publishing with F1000Research:

- Your article is published within days, with no editorial bias

- You can publish traditional articles, null/negative results, case reports, data notes and more

- The peer review process is transparent and collaborative

- Your article is indexed in PubMed after passing peer review

- Dedicated customer support at every stage

For pre-submission enquiries, contact research@f1000.com 